УдК 330.341 .1

\title{
ПРИНЦИПИ ПРОЄКТНО-ОРІЄНТОВАНОГО УПРАВЛІННЯ ІННОВАЦІЙНИМ РОЗВИТКОМ НАЦІОНАЛЬНОÏ ЕКОНОМІКИ
}

\author{
PRINCIPLES OF PROJECT-ORIENTED MANAGEMENT \\ OF INNOVATIVE DEVELOPMENT \\ OF THE NATIONAL ECONOMY
}

\author{
Старченко Григорій Володимирович \\ доктор економічних наук, доцент, \\ Національний університет «Чернігівська політехніка» \\ ORCID: https://orcid.org/0000-0003-2707-1055 \\ Starchenko Grygoriy \\ Chernihiv Polytechnik National University
}

\begin{abstract}
У статті виокремлена і надана сутність принципів проєктно-орієнтованого управління інноваційним розвитком національної економіки. Зазначено, що одним із способів підвищення конкурентоспроможності національної економіки $є$ робота на випередження, яка полягає у фрормуванні нових знань та інструментів методології проєктно-орієнтованого управління, яка є цілісним і комплексним підходом щодо управління інноваційним розвитком національної економіки із врахуванням впливу турбулентного зовнішнього середовища. Зазначене обумовило поширення методології проєктного менеджменту на ссреру загальноекономічних процесів. Обґрунтовано застосування проєктно-орієнтованого управління як необхідного теоретико-методологічного базису методології проєктно-орієнтованого управління інноваційним розвитком національної економіки. Виділені та показані логічні взаємозв'язки змістовних складових такої методології: знання (інфрормація, навички, норми, закони, категорії), принципи, процеси, інструменти (методи, техніки, засоби, процедури, прийоми). 3 урахуванням того, що остання версія стандарту РМВОК буде побудована на принципах, а не на процесах, важливою складовою методології проєктно-орієнтованого управління інноваційним розвитком національної економіки повинні бути принципи. Доведена необхідність застосування принципу двоконтурного управління, який передбачає рекомбінацію принципів механізму управління для двох взаємопов'язаних складових його фрункціонування окремо: для фрормування механізму проєктно-орієнтованого управління інноваційним розвитком та його реалізації, з огляду на досягнення цілей проєктів інноваційного розвитку.
\end{abstract}

Ключові слова: принципи, проєкт, інновація, розвиток, інноваційний розвиток, проєктно-орієнтоване управління.

В статье выделены и предоставлена сущность принципов проектно-ориентированного управления инновационным развитием национальной экономики. Отмечено, что одним из способов повышения конкурентоспособности национальной экономики является работа на опережение, которая заключается в формировании новых знаний и инструментов методологии проектно-ориентированного управления, которая является целостным и комплексным подходом к управлению инновационным развитием национальной экономики с учетом влияния турбулентной внешней среды. Указанное обусловило распространение методологии проектного менеджмента на сфреру общеэкономических процессов. Обосновано применение проектно-ориентированного управления как необходимого теоретико-методологического базиса методологии проектно-ориентированного управления инновационным развитием национальной экономики. Выделены и показаны логические взаимосвязи основных составляющих такой методологии: знание (информация, навыки, нормы, законы, категории), принципы, процессы, инструменты (методы, техники, средства, процедуры, приемы). С учетом того, что последняя версия стандарта РМВОК будет основываться на принципах, а не на процессах, важной составляющей методологии проектно-ориентированного управления инновационным развитием национальной экономики должны быть принципы. Доказана необходимость применения принципа двухконтурного управления, который предусматривает рекомбинацию принципов механизма управления для двух взаимосвязанных составляющих его фрункционирования отдельно: для фрормирования механизма проектно-ориентированного управления инновационным развитием и его реализации, с учитывая достижения целей проектов инновационного развития.

Ключевые слова: принципы, проект, инновация, развитие, инновационное развитие, проектно-ориентированное управление. 
The article structured and provided the essence of the principles of project-oriented management of innovative development of the national economy. The main goal of this work is identification and disclosure of the principles of project-oriented management of innovative development of the national economy. It is noted that one of the ways to improve the competitiveness of the national economy is to work ahead of the curve, which consists in the formation of new knowledge and tools of project-oriented management methodology. This methodology is a holistic and comprehensive approach to managing the innovative development of the national economy, taking into account the influence of a turbulent external environment. This circumstance led to the extension of the project management methodology to the sphere of general economic processes. The application of project-oriented management as a necessary theoretical and methodological basis for the methodology of project-oriented management of the innovative development of the national economy has been substantiated. To accomplish the tasks of the work, the following scientific methods were used: scientific research and generalization for determining the main principles of project-oriented management of innovative development of the national economy; a comparative method in the process of analyzing the systemic, functional, process, situational, institutional and synergetic approaches to understanding the nature of the innovative development of the national economy. The logical relationships of the main components of such a methodology are highlighted and shown: knowledge (information, skills, norms, laws, categories), principles, processes, tools (methods, techniques, means, procedures, techniques). Taking into account that the latest version of the PMBOK standard will be based on principles, and not on processes, principles should be an important component of the methodology of project-oriented management of innovative development of the national economy. The necessity of applying the principle of two-circuit control has been proved. This principle provides for the recombination of the principles of the control mechanism for its two interrelated components. Namely, separately for the formation of a mechanism for project-oriented management of innovative development and separately for its implementation. At the same time, it is necessary to take into account the goals of innovative development projects.

Keywords: principles, project, innovation, development, innovative development, project-oriented management.

Постановка проблеми. Проєктно-орієнтоване управління інноваційним розвитком національної економіки потребує застосування методології проєктного менеджменту, в якій закладені знання, за допомогою яких можна визначити мету, цілі, завдання, результати проєкту інноваційного розвитку, водночас через ґрунтовний аналіз проблем зменшити ризики реалізації таких проєктів.

На сьогодні, одним із способів підвищення конкурентоспроможності національної економіки є робота на випередження, яка полягає у формуванні нових знань та інструментів методології проєктно-орієнтованого управління, яка $€$ цілісним і комплексним підходом щодо управління інноваційним розвитком національної економіки із врахуванням впливу турбулентного зовнішнього середовища.

Сучасна методологія управління проєктами створювалась багатьма дослідниками та професійними менеджерами впродовж десятиліть. Вона була фрормалізована вченими у вигляді правил, настанов, документів, книг і т. п. Керівництво до зводу знань 3 управління проєктом PMBOK [1] який ще називають методологію управління проєктами PMI: Project Management Institute, сфрормульований у вигляді стандарту РMBOK, базується на концепції управління проєктами через групу стандартних процесів. Слід зауважити, що остання версія стандарту РМВОК відображає істотну корекцію методології в сторону ітеративних методик, тобто новий, сьомий, РМВОК буде principle-based, себто побудований на принципах, а не на процесах.
Аналіз останніх досліджень і публікацій. Вагомий внесок у дослідження сучасної методології проєктно-орієнтованого управління внесли закордонні та вітчизняні дослідники, зокрема таки, як: С. Бушуєв, К. Кошкін [2], В. Вайсман [3], Д. ДеКарло [4], І. Мазур, В. Шапіро [5], Дж. Тернер [6], А. Товб, Г. Ципес [7], Ф. Ярошенко [8] та інші.

Вказані науковці заклали значний фрундамент, що дає змогу розвинути основні теоретичні та методологічні положення проєктного менеджменту. Разом 3 тим, відкритим залишається питання поширення методології проєктного менеджменту на практичні аспекти управління інноваційним розвитком національної економіки. Визначення принципів проєктно-орієнтованого управління інноваційним розвитком національної економіки зумовлює подальші дослідження процесів управління інноваційним розвитком 3 точки зору методології проєктного менеджменту та формування механізму проєктно-орієнтованого управління інноваційним розвитком національної економіки.

Постановка завдання. Метою дослідження $€$ виокремлення і розкриття принципів проєктно-орієнтованого управління інноваційним розвитком національної економіки.

Виклад основного матеріалу дослідження. Методологію доцільно визначати як систему різноманітних методів, технік, засобів, норм, прийомів, процедур, принципів, законів та категорій наукового пізнання, 3 логічною, структурованою системою взаємозв'язків і 
взаємодій елементів, що іiі утворюють, та науку про цю систему.

Якщо дослідити зміст методології, то можна виокремити ключові її компоненти. Ці елементи сприяють ефективному управлінню на всіх стадіях життєвого циклу проєкту та наявні у різноманітних методологіях проєктного менеджменту (PRINCE2, P2M, OPM3, PMBOK, Agile, та ін) [9, с. 54].

Методологія проєктно-орієнтованого управління направлена на вдосконалення управління проєктами через використання спеціальних інструментів та стандартизацію процесів управління. В такій методології доцільно виділити їі змістовні складові - знання (інформація, навички, норми, закони, категорії), принципи, процеси, інструменти (методи, техніки, засоби, процедури, прийоми), склад та взаємозв'язки між цими елементами показані на рис. 1 [10, с. 112].

Під методологією проєктно-орієнтованого управління доцільно розуміти систему знань, принципів, процесів, інструментів проєктного менеджменту, 3 логічною, структурованою системою взаємозв'язків і взаємодій елементів, що її утворюють, та науку про цю систему.

Принципи, як головні, суттєві, важливі твердження $є$ центральним елементом методології проєктно-орієнтованого управління, якщо хоча б один 3 них не виконується, то не можна говорити про те, що проєкт виконується в рамках даної методології.

Тобто, для того щоб прийняти максимально ефективне проєктне рішення і провести зміни в об'єкті управління найкращим чином, суб'єкт управління повинен дотримуватися певних принципів, основними з яких доцільно виділити наступні [10]:

- Динамічність, полягає у тому, що здійснення проєкту відбувається в динамічному середовищі, яке діє на проєкт. Плинність та складність оточення проєкту, наявність великої кількості фракторів впливу, які не завжди можуть бути повною мірою враховані, що може призвести до невиконання проєкту.

- Ціленаправленість, або спрямованість проєктів на досягнення конкретних цілей. Проєкти реалізуються задля одержання певних результатів, тобто досягнення цілей, які $€$ рушійною силою проєкту. Проєкт припускає певний комплекс взаємозалежних цілей. Звідси випливає, що проєкт можна тлумачити як послідовне досягнення ретельно визначених цілей, виконання проєкту пов'язане 3 досягненням цілей вищого рівня, поки зрештою не буде досягнута фрінальна мета. Всі цілі повинні бути сорормульовані за SMART методикою, тобто бути: specific (конкретні), measurable (вимірювані), achievable or attainable (досяжні), relevant (актуальні), time bound (обмежені в часі).

- Координоване виконання взаємозалежних дій. Проєкт є динамічною системою, що складається із взаємозалежних елементів, ці елементи містять у собі велику кількість взаємозалежних дій, які вимагають координованого виконання, тому це потребує застосування специсрічних підходів до управління. Якщо синхронізація реалізації різних завдань відсутня, завершення проєкту може бути під загрозою.

- Проєкт як система обмежена тривалістю у часі, тобто він закінчиться, коли будуть досягнуті його основні цілі й буде одержаний його кінцевий результат. Проєкт має більш-менш чітко виражений початок і кінець. При виконанні проєкту значна частина зусиль повинна бути спрямована на забезпечення завершення проєкту у намічений термін.

- Проєкти є унікальними та деякою мірою неповторними. Унікальність проєкту пов'язана як з кінцевими цілями проєкту, так і з умовами їх досягнення. Проєктам з високою унікальністю притаманна висока невизначеність та їх складніше реалізовувати.

-Принцип системності, полягає у тому, що з точки зору системного підходу проєкт є системою яка складається із взаємопов'язаних елементів яка фрункціонує для досягнення визначеної мети в умовах обмежених ресурсів. Також слід зазначити, що процес управління проєктами $€$ однією цілою системою яка фрункціонує і розвивається на основі певних законів. Проєкт складається з підсистем кожна $з$ яких впливає як на всі інші підсистеми, так і на проєкт в цілому.

- Принцип холістичності випливає із принципу системності, згідно з яким підсистеми проєкту складають внутрішню єдність, та пов'язані між собою у єдине ціле.

- Принцип безперервності в управлінні проєктами, який вимагає корегування робіт за проєктами в міру необхідності під час отримання нових даних про об'єкт управління.

- Принцип комплексності, який передбачає аналіз явищ в їх зв'язку і залежності, припускає спільне використання та застосування різноманітних фрорм та методів управління проєктами при їх розробці і реалізації, взаємозв'язок окремих підсистем проєкту між собою і з головною ціллю проєкту та розгляд окремих задач проєкту з точки зору часових інтервалів. 


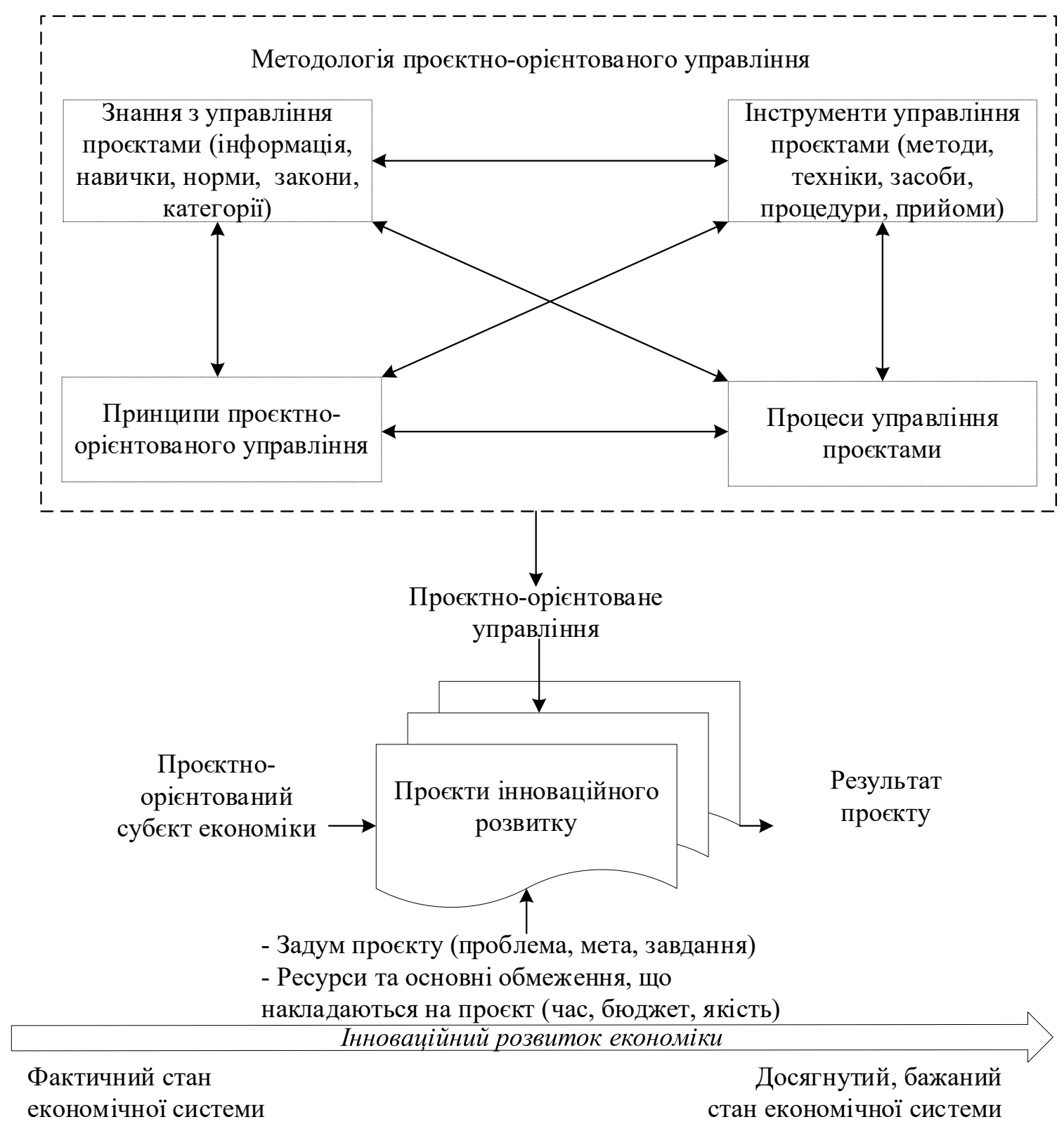

Рис. 1. Змістовні складові методології проєктно-орієнтованого управління

Джерело: розроблено автором

- Принцип забезпеченості полягає в тому, що всі роботи, які передбачені проєктом, повинні бути забезпечені ресурсами, які необхідні для його реалізації.

- Принцип пріоритетності означає, що при розробці і реалізації проєкту перевага повинна надаватися першочерговим роботам, виходячи з загальної мети проєкта.

- Принцип ризикованості полягає в тому, що економічна безпека робіт, що плануються повинна визначатися виходячи з оцінки ймовірності виникнення збитків або втрат в результаті невиконання запланованих проєктом задач.

- Принцип об'єктивності управління - процес управління залежить від окремих об'єктів, а істина пізнається через складний взаємозв'язок елементів суб'єктно-об'єктних відносин.

- Нелінійність структури управління проєктом, ефрективність реалізації проєкту залежить від його організаційної структури, від того наскільки вона узгоджена із структурою суб'єкта економіки, в якому реалізується проєкт. Найбільш застосованими в управлінні проєктами типами організаційних структур є матрична і проєктна.

- Наявність визнаних світових стандартів управління проєктами, що дістали міжнародне значення та визнання в процесі свого розвитку, в яких відображається сучасна методологія управління проєктами. 
Методологія проєктного менеджменту дала змогу акцентувати увагу на таких параметрах сучасних проєктів інноваційного розвитку як: складність, невизначеність, високий пріоритет, ризикованість, транспарентність, динамізм, імерджентність. Відзначені параметри уможливлюють визначення єдиної траєкторії досягнення цілей інноваційного розвитку економіки країни. Це обумовлює необхідність ідентисрікації множини кінцевих результатів, на які буде сконцентрована траєкторія змін від реалізації проєкту інноваційного розвитку з урахуванням впливу екзогенних та ендогенних сракторів розвитку економіки. Доцільним буде застосування принципу двоконтурного управління, який передбачає рекомбінацію принципів механізму управління для двох взаємопов'язаних складових його функціонування окремо: для фрормування механізму проєктно-орієнтованого управління інноваційним розвитком та його реалізації, з огляду на досягнення цілей проєктів інноваційного розвитку (рис. 2).
Це сприятиме розмежуванню принципів на дві групи: фрормування механізму (законності, обґрунтованості, адресності, ефрективності, транспарентності та гласності, науковості, адаптації, гнучкості, системності, етапності та поступальності, цілеспрямованості, динамічності, неперервності, збалансованості, узгодженості) та його реалізації (координованості, лімітованості, унікальності, холістичності, комплексності, забезпеченості, ризикованості, пріоритетності, системності, об'єктивності управління, таргетування, динамічності, безперервності, нелінійності, стандартизованості).

Методологіяпроєктно-орієнтованогоуправління інноваційним розвитком національної економіки має міждисциплінарний характер. Теоретико-методологічний базис методології проєктно-орієнтованого управління інноваційним розвитком національної економіки сформований на основі узагальнення системного, фрункціонального, процесного, ситуаційного, інституційного та синергетичного підходів
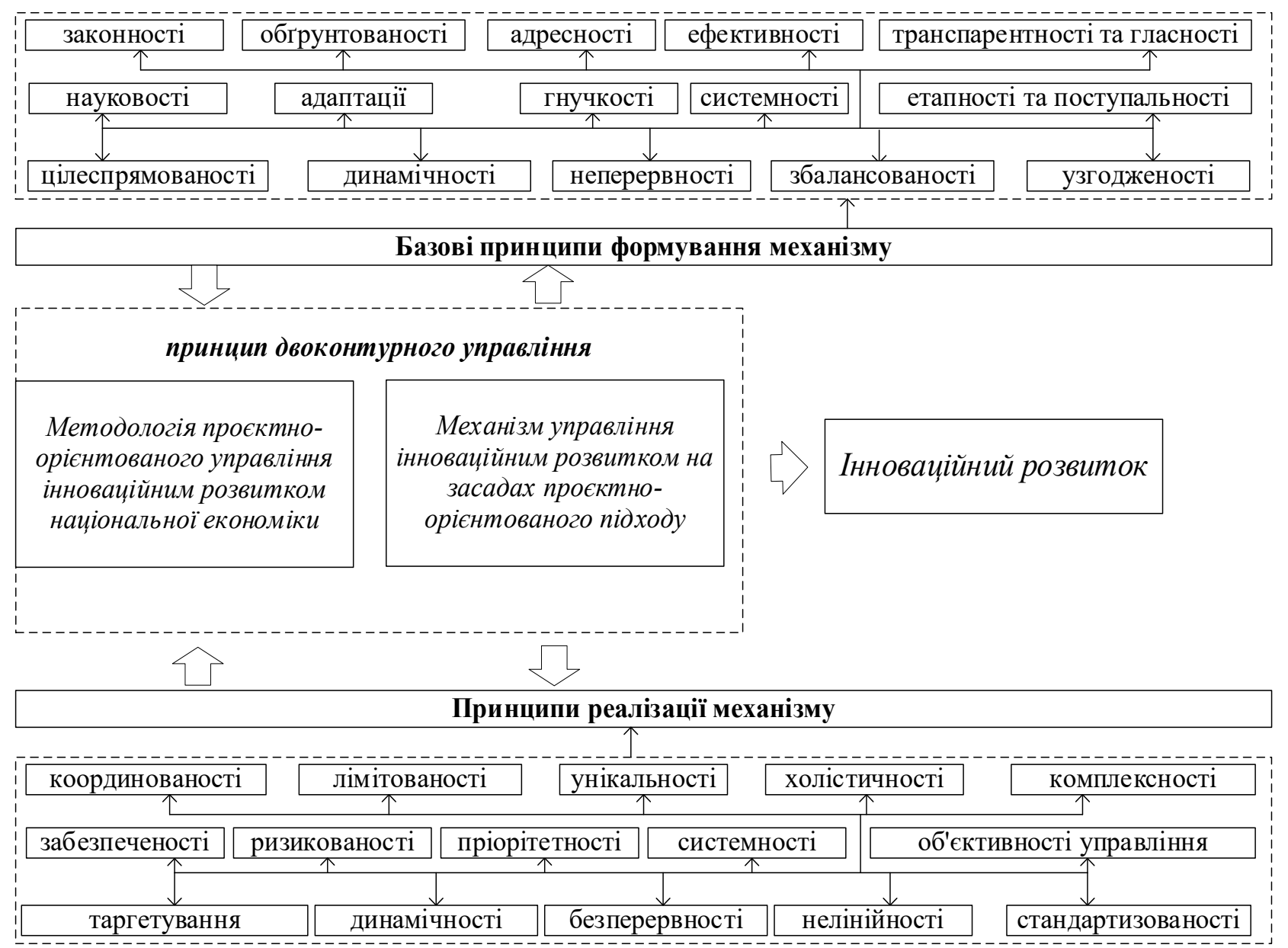

Рис. 2. Структурно-логічна схема рекомбінації принципів

проєктно-орієнтованого управління інноваційним розвитком національної економіки 
до пізнання природи інноваційного розвитку національної економіки.

Виокремлення принципів проєктно-орієнтованого управління інноваційним розвитком національної економіки з позиції поєднання положень синергетики та проєктного менеджменту дає змогу обґрунтувати необхідність спрямованості організаційних заходів на повніше використання економічних важелів стимулювання інноваційної трансформації суспільства.

Висновки з проведеного дослідження. Отже, формування нової методологічної парадигми управління інноваційним розвитком національної економіки, поява нових підходів, які, спрямовують дослідження в певне русло, вимагають використання певних прин- ципів проєктно-орієнтованого управління, поза формуванням якої управління може бути неякісним, все це призводить до зміни нашої уяви про принципи такого управління.

До того ж розвиток економічної науки, теорії пізнання останнім часом усе потужніше окреслює потребу у використанні в сорері економічних досліджень міждисциплінарних підходів, що, безперечно, означає, як ускладнення методології досліджень, так і поглиблення їх синергетичного ефректу, оскільки дозволяє пізнати об'єкт аналізу з таких сторін і фрорм прояву, які були недоступні при використанні суто економічних методів, отже забезпечує більш широкі можливості впливу на внутрішні важелі економічного та соціального розвитку, забезпечуючи тим самим поступальний прогрес людства.

\section{СПИСОК ВИКОРИСТАНИХ ДЖЕРЕЛ:}

1. A Guide to the Project Management Body of Knowledge (PMBOK® Guide). Newtown Square, PA : Project Management Institute, 2017. 762 p.

2. Бушуєв С.Д., Гогунський В.Д., Кошкін К.В. Напрями дисертаційних наукових досліджень зі спеціальності управління проектами та програмами. Управління розвитком складних систем. 2012. № 12. С. 5-7.

3. Вайсман В.А., Гогунський В.Д., Руденко С.В. Теория проектно-ориентованого управления: обоснование закона Бушуева С.Д. Наук. записки Міжнар. гуманітарного ун-ту : Зб. / під. ред. д.т.н., проф. Рибака А.І. 2009. Вип. 16. : Серія «Управління проектами та програмами». С. 9-13.

4. ДеКарло Д. Экстремальное управление проектами / Пер. с англ. Финогенова М.С., Смыковской Е.И.; Науч. ред. Баженов А.Д, Арефьев А.О. Москва : Компания р.m. Offlce, 2005. 588 с.

5. Мазур И.И., Шапиро, В.Д., Ольдерогге, Н.Г. Управление проектами. Москва : Омега-Л, 2007. 664 с.

6. Тернер Дж. Родни. Руководство по проектно-ориентированному управлению; пер.с англ. под общ. ред. В.И. Воропаева. Москва : издательский дом Гребенникова, 2007. 552 с.

7. Товб А.С., Ципес, Г.Л. Управление проектами: стандарты, методы, опыт. Москва : ЗАО «Олимп-Бизнес», 2003. $240 \mathrm{c}$.

8. Бушуєва Н.С., Ярошенко Р.Ф., Ярошенко Т.О. Проактивне управління програмами розвитку фінансових установ в умовах турбулентного оточення. Управління розвитком складних систем. 2011. № 7. С. 16-19.

9. Тесля Ю.М., Хлевна Ю.Л., Єгорченкова Н.Ю. Управління знаннями в мета-методології управління проектами. Управління проектами та розвиток виробництва : Зб. наук. пр. Луганськ : вид-во СНУ ім. В. Даля, 2016. № 4(60). C. 53-61.

10.Старченко Г.В. Проектно-орієнтоване управління інноваційним розвитком національної економіки: теорія, методологія та практика : монографія. Київ : ВАДЕКС, 2019. 326 с.

\section{REFERENCES:}

1. Newtown Square, PA: Project Management Institute (2017). A Guide to the Project Management Body of Knowledge (PMBOK® Guide).

2. Bushujev, S.D., Ghoghunsjkyj, V.D. \& Koshkin, K.V. (2012). Naprjamy dysertacijnykh naukovykh doslidzhenj zi specialjnosti upravlinnja proektamy ta proghramamy [Directions dissertation research specialty "project and program management"]. Upravlinnja rozvytkom skladnykh system, 12, 5-7. (in Ukrainian)

3. Vaisman, V.A., Hohunskyi, \& V.D.Rudenko, S.V. (2012). Teoryia proektno-oryentovanoho upravlenyia: obosnovanye zakona Bushueva S.D. [The theory of project-oriented management: substantiation of the law Bushuev S.D.]. Nauk. zapysky Mizhnar. humanitarnoho un-tu: Zb. / pid. red. d.t.n., prof. Rybaka A.I. Vyp. 16. Seriia "Upravlinnia proektamy ta prohramamy", 9-13. (in Ukrainian)

4. DeKarlo D. (2005). Ekstremal'noe upravlenie proektami [Extreme project management]. In A.D. Bazhenov, \& A.O. Aref'ev (Eds). Moscow: Kompaniya p.m. Offlce. (in Russian)

5. Mazur, I.I., Shapiro, V.D. \& Ol'derogge, N.G. (2007). Upravlenie proektami [Project management]. Moscow: Omega-L. (in Russian) 
6. Terner D.R. (2007). Rukovodstvo po proektno-orientirovannomu upravleniyu [Project Oriented Management Guide]. In V.I. Voropaev (Eds). Moscow: Izdatel'skiy dom Grebennikova. (in Russian)

7. Tovb, A.S., \& Tsipes, G.L. (2003). Upravlenie proektami: standarty, metody, opyt [Project management: standards, methods, experience]. Moscow: ZAO «Olimp-Biznes». (in Russian)

8. Bushuieva, N.S., Yaroshenko, R.F., \& Yaroshenko, T.O. (2011). Proaktyvne upravlinnia prohramamy rozvytku finansovykh ustanov $v$ umovakh turbulentnoho otochennia [Proactive management of financial institution development programs in a turbulent environment]. Upravlinnja rozvytkom skladnykh system, 7, 16-19. (in Ukrainian)

9. Teslia, Yu.M., Khlevna, Yu.L., \& Yehorchenkova, N.Yu. (2016). Upravlinnia znanniamy v meta-metodolohii upravlinnia proektamy [Knowledge management in project management meta-methodology]. Upravlinnia proektamy ta rozvytok vyrobnytstva: Zb. nauk. pr. Luhansk: vyd-vo SNU im. V. Dalia, 4(60), 53-61. (in Ukrainian)

10. Starchenko G.V. (2019). Proektno-oriientovane upravlinnia innovatsiinym rozvytkom natsionalnoi ekonomiky: teoriia, metodolohiia ta praktyka: monohrafiia [Project-oriented management of innovative development of the national economy: theory, methodology and practice: monograph]. Kyiv: VADEKS. (in Ukrainian) 